\title{
Physicomechanical characterization and biological evaluation of bulk-fill composite resin
}

\section{Armiliana Soares NASCIMENTO(a) Daniel Bezerra LIMA(b) \\ Marcus Vinicius Lia FOOK(b) Monica Soares de ALBUQUERQUE(a) Eliane Alves de LIMA(a) \\ Marcos Antonio SABINO(c) \\ Silvia Maria Pinto BORGES ${ }^{(b)}$ \\ Pedro Tardelly Diniz FILGUEIRA ${ }^{(a)}$ Yasmine Carvalho de SOUSA ${ }^{(a)}$ Rodivan BRAZ(a)}

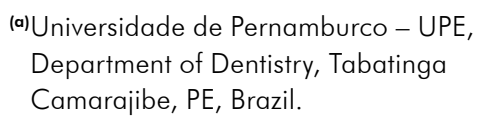

(b) Universidade Federal de Campina Grande UFCG, Department of Materials Science and Engineering, Campina Grande, PB, Brazil.

(c) Universidad Simón Bolivar - USB, Department of Chemistry, Caracas, Venezuela.

Declaration of Interest: The authors certify that they have no commercial or associative interest that represents a conflict of interest in connection with the manuscript.

Corresponding Author: Armiliana Soares Nascimento E-mail: armiliana@hotmail.com

https://doi.org/10.1590/1807-3107bor-2018.vol32.0107

Submitted: January 22, 2018

Accepted for publication: May 21, 2018

Last revision: August 30, 2018
Abstract: The aim of this study was to evaluate the cytotoxic effect, degree of conversion (\% DC), Vickers hardness (VH), and surface morphology of composite resins. Eleven resins, nine bulk-fill resins, and two conventional resins were evaluated. Each material was sampled to evaluate DC (using FTIR), VH, cytotoxicity (using MTT and Neutral Red - NR test), surface morphology (using SEM and AFM), and organic filler (using EDS). All statistical tests were performed with SPSS and the level of significance was set at 0.05 . MTT revealed that the materials presented low or no cytotoxic potential in relation to the control. Opus was the resin with the lowest cell viability at a 1:2 concentration at $72 \mathrm{~h}(32 \%)$ and at 7 days (43\%), but that significantly increased when the NR test was applied at a 1:2 concentration after 7 days. Thickness and surface subjected to polymerization had no influence on DC, and differences were observed only between the materials. In the microhardness test, statistical differences were observed between the evaluated thicknesses. The bulk-fill resins analyzed in this study exhibited low and/or no cytotoxicity to L929 cells, except for Opus, which showed moderate cytotoxicity according to the MTT assay. When the NR test was used, results were not satisfactory for all composites, indicating the need for different methodologies to evaluate the properties of these materials. The assessed resins demonstrated acceptable physicomechanical properties.

Keywords: Composite Resins; Biocompatible Materials; In Vitro Techniques.

\section{Introduction}

The use of composite resins in restorative procedures has increased over the years, especially because of their aesthetic properties. However, there is still considerable concern about polymerization shrinkage, degree of conversion, and biocompatibility/cytotoxicity. ${ }^{1}$ The cytotoxicity of these materials has been associated with the quantity and type of residual monomer released, and studies have shown a correlation between this phenomenon and mass loss and/or low degree of conversion. ${ }^{2}$ Although composite resins are biologically accepted, there has been evidence of allergic effects on oral mucosal tissues, ${ }^{3}$ due to the dissolution of methacrylate and leaching of its components, ${ }^{4}$ resulting from masticatory forces and chemical degradation. ${ }^{5}$ 
Thus, composite resins, known as bulk-fill resins, with modifications in their chemical formulation and polymerization properties, have been developed to minimize or eliminate polymerization shrinkage, increasing the depth of polymerization as well as cytotoxicity. Bulk-fill resins with a 4-6 mm single increment have low shrinkage stress and a high degree of polymerization at this depth, due in particular to the increase in translucency and to the presence of polymerization modulators. ${ }^{6,7}$ However, what is not clear is whether the degree of conversion at this depth is compromised, which would increase the cytotoxic potential, especially in the case of bulk-fill flowable resins with a higher organic matter content. ${ }^{8,9}$ Therefore, given the difficulties of in vivo studies, this in vitro study investigated the degree of conversion, microhardness, surface morphology, and cytotoxicity of newly developed composites. Three hypotheses were tested: the differences in time and concentration of the assessed composite resin samples would not make them potentially cytotoxic to cells. There would be no difference between the methods used for evaluating cytotoxicity. The degree of conversion and microhardness would not be dependent on material thickness or on the surface subjected to polymerization.

\section{Methodology}

\section{Sample preparation}

Nine bulk-fill resins - Aura Bulk Fill (SDI, Australia), Filtek Bulk Fill Flow (3MESPE, Germany), Filtek Bulk Fill Sculptable (3MESPE, Germany), Surefil SDR ${ }^{+}$(Dentsply, Germany), Tetric EvoFlow Bulk Fill (Ivoclar-Vivadent, Liechtenstein), Admira Fusion (Voco, Germany) X-tra Fil (Voco, Germany), X-tra Base (Voco, Germany), Opus (FGM, Brazil); and two conventional resins - Filtek Z350XT (3MESPE, Germany) and Filtek Z350 Flow (3MESPE, Germany), were evaluated (Table 1).

Samples of each material with $5 \mathrm{~mm}$ in diameter and $2 \mathrm{~mm}$ and $4 \mathrm{~mm}$ in thickness were prepared for assessment of degree of conversion and Vickers hardness. In order to avoid inhibition of oxygen, a transparent polyester strip was placed on the top and bottom of the mold, and resins were inserted and photopolymerized with a LED device (KaVo Poly Wireless, KaVo - Brazil) according to the manufacturer's instructions (Table 1). All specimens were stored in distilled water for $24 \mathrm{~h}$ at $37^{\circ} \mathrm{C}$ prior to testing. For the cytotoxicity test, discs of each material $(5 \times 4 \mathrm{~mm}, \mathrm{n}=2)$ were prepared under aseptic conditions, using sterile material and a laminar flow cabinet, to reduce any risk of biological contamination of the cells. Thereafter, the samples were placed in 24-well plates with $200 \mu \mathrm{L}$ of culture medium (RPMI -1640) at two different time intervals (72 $\mathrm{h}$ and 7 days) at $37^{\circ} \mathrm{C}$ and $5 \% \mathrm{CO}_{2}$, to obtain the extracts.

\section{Cell culture and cytotoxicity assay (MTT assay)}

The fibroblast cell line was obtained from ATCC (ATCC ${ }^{\circledast}$ L929), and cells were grown in RPMI 1640 medium containing L-glutamine, sodium pyruvate, and $2.0 \mathrm{~g} / \mathrm{L}$ of $\mathrm{NaHCO} 3$ supplemented with $10 \%$ fetal bovine serum (FBS), and 1\% penicillin-streptomycin (Gibco® Anti-anti (100X), USA) at $37^{\circ} \mathrm{C}$ and $5 \% \mathrm{CO}_{2}$. Cell density was evaluated and cells were exposed to $2 \mathrm{~mL}$ of trypsin solution (0.25\%) - Sigma-Aldrich (Sigma Chemical Co., St. Louis, MO, USA) for $5 \mathrm{~min}$, neutralized with the same amount of culture medium, and cell viability was then assessed. Subsequently the cells were seeded in 96-well plates (TPP, Darmstadt, Germany) at the concentration of $1 \times 10^{5}$ cells $/ \mathrm{mL}$ per well, each containing $100 \mu \mathrm{L}$ of medium, for $24 \mathrm{~h}$ at $37^{\circ} \mathrm{C}$ and $5 \% \mathrm{CO}_{2}$. After that, the medium was removed and replaced with the extracts of the diluted resin to obtain 1:2 and 1:10 concentrations. The negative control consisted of cells treated with culture medium only. Cell metabolism was evaluated by the MTT (3-(4,5-Dimethylthiazol-2-yl)-2,5-diphenyltetrazolium bromide)) assay, in accordance with the BS EN ISO $10993-5^{10}$ standard, and absorbance was measured at $570 \mathrm{~nm}$ and $650 \mathrm{~nm}$ using a spectrophotometer (PerkinElmer VICTOR ${ }^{\mathrm{TM}}$ X3). Grubbs' test was used to eliminate outliers, and cell viability was estimated considering the negative control at $100 \%$.

\section{Neutral red incorporation}

L929 cells were seeded in 96-well plates at the concentration of $1 \times 10^{5}$ cells/well using Dulbecco's modified Eagle's medium (DMEM) without phenol red and kept in an oven with $5 \% \mathrm{CO}_{2}$ at $37^{\circ} \mathrm{C}$ for $24 \mathrm{~h}$. Thereafter, the medium was removed and added to the 
Table 1. Materials used in the study (Information provided by manufacturers).

\begin{tabular}{|c|c|c|c|c|c|c|}
\hline Code & $\begin{array}{l}\text { Material and } \\
\text { Manufacturing batch no }\end{array}$ & Monomers & Fillers & $\begin{array}{l}\text { Photoinitiators/ } \\
\text { Co-initiators }\end{array}$ & Shade & $\begin{array}{l}\text { Thickness }(\mathrm{mm}) / \text { Curing } \\
\text { Time and Light Intensity }\end{array}$ \\
\hline$A B F$ & $\begin{array}{l}\text { Aura bulk fill (SDI, São } \\
\text { Paulo, Brazil) - } 150931\end{array}$ & n.i & n.i & n.i & U & $\begin{array}{c}4 \mathrm{~mm} / 20 \mathrm{~s} \geq 1000 \mathrm{~mW} / \\
\mathrm{cm}^{2} \text { (LED) or } 2 \times 20 \mathrm{~s} \\
\text { (halogen light). }\end{array}$ \\
\hline FBFF & $\begin{array}{c}\text { Filtek Bulk Fill Flow }{ }^{T M}(3 M / \\
\text { ESPE St. Paul, MN, USA) - } \\
\text { N735392 }\end{array}$ & $\begin{array}{l}\text { Bis-GMA, } \\
\text { UDMA } \\
\text { Bis-EMA, } \\
\text { Procrylat }\end{array}$ & $\begin{array}{c}\text { Ytterbium trifluorite } \\
\text { zirconia/silica - 64wt \%, } \\
42.5 \mathrm{vol}\end{array}$ & n.i & A2 & $\begin{array}{c}4 \mathrm{~mm} / 20 \mathrm{~s} \geq 1000 \mathrm{~mW} / \\
\mathrm{cm}^{2} \text { or } 40 \mathrm{~s} 550-1000 \mathrm{~mW} / \\
\mathrm{cm}^{2} \text { (halogen or LED) }\end{array}$ \\
\hline FBFS & $\begin{array}{l}\text { Filtek Bulk'M Fill Sculptable } \\
\begin{array}{c}\text { (3M/ESPE St. Paul, MN, USA) } \\
- \text { N686825 }\end{array}\end{array}$ & $\begin{array}{l}\text { Bis-GMA, } \\
\text { AUDMA, } \\
\text { UDMA, DDMA }\end{array}$ & $\begin{array}{l}\text { Silica, zirconia, ytterbium } \\
\text { trifluorite, zirconia/silica - } \\
\quad 76.5 \mathrm{w} \%, 58.4 \mathrm{vol}\end{array}$ & n.i & A2 & $\begin{array}{l}4 \mathrm{~mm} / 20 \mathrm{~s} \geq 1000 \mathrm{~mW} / \mathrm{cm}^{2} \\
\text { (LED) or } 40 \mathrm{~s} \\
550-1000 \mathrm{~mW} / \mathrm{cm}^{2} \\
\text { (halogen light). }\end{array}$ \\
\hline SDR & $\begin{array}{c}\text { SureFil }^{\circledR} \text { SDR Flow }{ }^{\text {TM }} \\
\text { (DENTSPLY Petropolis, Brazil) } \\
\quad-160613\end{array}$ & $\begin{array}{l}\text { Modified } \\
\text { UDMA } \\
\text { EBPADMA } \\
\text { TEGDMA }\end{array}$ & $\begin{array}{l}\text { Barium and strontium } \\
\text { alumino-fluoro silicate } \\
\text { glasses - } 68 \mathrm{w}+\%, 44 \mathrm{vol} \%\end{array}$ & $\begin{array}{l}\text { Camphorquinone } \\
\text { (CQ), BHT, UV } \\
\text { stabilizer, titanium } \\
\text { dioxide, iron } \\
\text { oxide pigments, } \\
\text { fluorescEagent }\end{array}$ & U & $\begin{array}{c}4 \mathrm{~mm} / 20 \mathrm{~s} 500-1000 \mathrm{~mW} / \mathrm{cm}^{2} \\
\text { (LED and halogen) or } 10 \mathrm{~s} \\
\text { (high power lights). }\end{array}$ \\
\hline
\end{tabular}

\begin{tabular}{|c|c|c|c|c|c|c|}
\hline AF & $\begin{array}{l}\text { Admira Fusion x-tra } \\
\text { (VOCO Cuxhaven, } \\
\text { Germany) - } 1619518\end{array}$ & n.i & Inorganic fillers - $84 w+\%$ & n.i & $U$ & $\begin{array}{l}4 \mathrm{~mm} / 20 \mathrm{~s} \geq 800 \mathrm{~mW} / \mathrm{cm}^{2} \\
\text { or } 40 \mathrm{~s} 500-800 \mathrm{~mW} / \mathrm{cm}^{2}\end{array}$ \\
\hline TEF & $\begin{array}{l}\text { Tetric EvoFlow Bulk Fill } \\
\text { (IVOCLAR VIVADENT } \\
\text { Amherst, } \\
\text { NY, USA) - U41169 }\end{array}$ & $\begin{array}{l}\text { Bis-GMA } \\
\text { Bis-EMA } \\
\text { UDMA }\end{array}$ & $\begin{array}{l}\text { Prepolymer fillers, barium } \\
\text { glass filler, ytterbium } \\
\text { fluoride, and spherical } \\
\text { mixed oxide fillers - } 62.5 \\
\text { wt } \%, 60 \text { vol\% }\end{array}$ & $\begin{array}{l}\text { Camphorquinone } \\
\text { /amine - highly } \\
\text { reactive, patented } \\
\text { Ivocerin light initiator }\end{array}$ & $U$ & $\begin{array}{c}4 \mathrm{~mm} / 20 \mathrm{~s} \geq 600 \mathrm{~mW} / \mathrm{cm}^{2} \\
10 \mathrm{~s} \geq 1000 \mathrm{~mW} / \mathrm{cm}^{2}\end{array}$ \\
\hline XTB & $\begin{array}{c}\text { X-tra Base (VOCO } \\
\text { Cuxhaven, Germany) - } \\
1621410\end{array}$ & n.i & $\begin{array}{c}\text { Inorganic fillers - } 75 \mathrm{w}+\% \\
58 \text { vol\% }\end{array}$ & $\mathrm{n} . \mathrm{i}$ & $U$ & $\begin{array}{l}4 \mathrm{~mm} / 10 \mathrm{~s} \geq 800 \mathrm{~mW} / \mathrm{cm}^{2} \\
\text { or } 10 \mathrm{~s} 500-800 \mathrm{~mW} / \mathrm{cm}^{2}\end{array}$ \\
\hline XTF & $\begin{array}{l}\text { X-tra Fill (VOCO Cuxhaven, } \\
\text { Germany) - } 1547611\end{array}$ & $\begin{array}{l}\text { Bis-GMA, } \\
\text { UDMA, } \\
\text { TEGDMA }\end{array}$ & $\begin{array}{c}\text { Inorganic fillers - } 75 \mathrm{wt} \% \\
70.1 \text { vol\% }\end{array}$ & n.i & $U$ & $\begin{array}{l}4 \mathrm{~mm} / 10 \mathrm{~s} \geq 800 \mathrm{~mW} / \mathrm{cm}^{2} \\
\text { or } 20 \mathrm{~s} 500-800 \mathrm{~mW} / \mathrm{cm}^{2}\end{array}$ \\
\hline Opus & $\begin{array}{c}\text { OPUS Bulk Fill Flow } \\
\text { (FGM, Joinville, SC, Brazil) - } \\
010816\end{array}$ & $\begin{array}{c}\text { Urethane } \\
\text { Dimethacrylate } \\
\text { (UDMA) } \\
\text { Monomers }\end{array}$ & $\begin{array}{l}\text { Silicon dioxide (silica) } \\
\text { silanized. }\end{array}$ & Camphorquinone & $\mathrm{Al}$ & $4 \mathrm{~mm} / 20 \mathrm{~s} \geq 450 \mathrm{~mW} / \mathrm{cm}^{2}$ \\
\hline Z350F & $\begin{array}{c}\text { Filtek Z350 XT Flow }{ }^{\top M} \\
\text { universal restorative (3M } \\
\text { ESPE, St Paul, MN, USA) - } \\
1605300512\end{array}$ & $\begin{array}{l}\text { BisEMA, } \\
\text { TEGDMA, } \\
\text { Procrylat } \mathrm{K}\end{array}$ & $\begin{array}{l}\text { Ytterbium fluoride and } \\
\text { silica } \\
\text { Silica/zirconia - } 65 \mathrm{wt} \% \text {, } \\
46 \text { vol\% }\end{array}$ & n.i & A2 & $\begin{array}{c}2 \mathrm{~mm} / 20 \mathrm{~s} 500-1000 \mathrm{~mW} / \\
\mathrm{cm}^{2} \text { (LED and halogen) or } \\
10 \mathrm{~s} \text { (high power lights). }\end{array}$ \\
\hline Z350 & $\begin{array}{c}\text { Filtek Z350 XT Flow }{ }^{\mathrm{TM}} \\
\text { universal restorative (3M } \\
\text { ESPE, St Paul, MN, USA) - } \\
236236\end{array}$ & $\begin{array}{l}\text { UDMA, } \\
\text { BisEMA, } \\
\text { BisGMA, } \\
\text { TEGDMA, } \\
\text { PEGDMA }\end{array}$ & $\begin{array}{c}\text { Silica, zirconia, silica/ } \\
\text { zirconia }-72.5 w+\%, 55.6 \\
\text { vol\% }\end{array}$ & n.i & A2 & $\begin{array}{c}2 \mathrm{~mm} / 20 \mathrm{~s} \geq 400 \mathrm{~mW} / \mathrm{cm}^{2} \\
\text { (LED or halogen light). }\end{array}$ \\
\hline
\end{tabular}

UDMA: urethane dimethacrylate; Bis-GMA: bisphenol A glycidyl methacrylate; Bis-EMA: ethoxylated bisphenol A glycol dimethacrylate; EBADMA: ethoxylated bisphenol A dimethacrylate, EDMAB: ethyl-4-dimethylaminobenzoate; DDDMA: 1,12-dodecane-DMA; TEGDMA: Tetraethylene glycol dimethacrylate; PEGDMA: Poly(ethylene glycol) diacrylate; n.i - no information provided by the manufacturer 
medium with the extracts (1:2 and 1:10 concentrations), and incubated again for $24 \mathrm{~h}$ at $37^{\circ} \mathrm{C}$ and $5 \% \mathrm{CO}_{2}$. The supernatant of the media with the extracts was discarded, and $100 \mu \mathrm{L}$ of neutral red $(50 \mu \mathrm{g} / \mathrm{mL}$, Sigma Aldrich, USA), previously incubated for $12 \mathrm{~h}$, was added. After allowing some time for the cells to take up the neutral red, the medium was removed and cells were washed twice with PBS - Dulbecco for eliminating excessive extracellular dye and photographing cell condition. Then, a lysis solution ( $1 \%$ acetic acid and $49 \%$ absolute ethanol) was added in order to extract the neutral red incorporated into lysosomes. The plate was stirred for $30 \mathrm{~min}$ and absorbance was measured at $540 \mathrm{~nm}$ with a spectrophotometer (PerkinElmer VICTOR $^{\mathrm{TM}} \mathrm{X}$ ). Grubbs' test was used to eliminate the outliers, and cell viability was estimated considering the negative control at $100 \%$.

\section{Degree of conversion (\% DC)}

The unpolymerized material and the top and bottom surfaces of the photopolymerized samples were analyzed by FTIR using a spectrophotometer (Perkin Elmer, Norwalk, USA) equipped with attenuated total reflection (ATR), at 4,000-650 nm. Thirty-two scans were taken of each sample $(\mathrm{n}=3)$ with a resolution of $2.0 \mathrm{~cm}^{-1}$. Peak heights at $1,637 \mathrm{~cm}^{-1}$ (aliphatic carbon-carbon bonds) and at 1,608 $\mathrm{cm}^{-1}$ (aromatic carbon-carbon bonds) were measured using the normalized baseline method, on the same equipment, and the \% DC values of the monomers were determined by the following equation:

$$
\% \mathrm{DC}=\left[1-\left(\frac{\frac{1637 \mathrm{~cm}^{-1}}{1608 \mathrm{~cm}^{-1}} \text { Peak height cured }}{\frac{1637 \mathrm{~cm}^{-1}}{1608 \mathrm{~cm}^{-1}} \text { Peak height uncured }}\right)\right] \times 100
$$

\section{Vickers hardness (VH)}

Vickers hardness test was performed with a digital microdurometer (FM 700, Future Tech Corp., Equilam, Tokyo, Japan), with a 50-kg load applied for $15 \mathrm{~s}$. Three readings were taken from the top and bottom of the test specimens ( $2 \mathrm{~mm}$ and $4 \mathrm{~mm}$ ), and a final mean was obtained for each sample $(n=5)$. The length of the diagonals ( $d 1$ and $d 2$ ), left in the specimens by the penetrator, was digitally measured by a light microscope coupled to the microdurometer.

\section{Surface morphology analysis (SEM and AFM) and identification of chemical elements (EDS)}

For the surface morphology analysis, a sample of each material was subjected to finishing and polishing procedures, performed in a single direction, for 15 s, with Sof-Lex discs (high, medium, fine, and ultrafine, respectively), according to the manufacturer's instructions. A new disc was used for each sample. The specimens were cleaned in an ultrasonic tank for $5 \mathrm{~min}$ at $50^{\circ} \mathrm{C}$ and then washed with distilled water and dried at room temperature (30 $\mathrm{min})$. Afterwards, the samples were examined by low vacuum scanning electron microscopy-SEM(PHENOM proX, ANACOM Scientific) with detector operating at $15 \mathrm{Kv}$. Images from a representative area of the surfaces of the composite resins were obtained at 500X and 3,000X magnification. In addition, energy dispersive X-ray spectroscopy (EDS) was performed to determine the chemical elements present at the point of the incident beam. Three areas of each sample were selected for EDS reading.

Atomic force microscopy (AFM) was performed in one sample of each material using a commercial AFM (Veeco Metrology Group, Santa Barbara, CA, USA) in contact mode (cantilevers) with a spring constant of 0.1 $\mathrm{N} / \mathrm{m}$ and OTR 8-35 Nanoprobe SPM tips. Images $(30 \times 30$ $\mu \mathrm{m})$ were obtained with a resolution of $512 \times 512$ pixels and analyzed using dedicated software (Nanoscope v616r1, Veeco Metrology Group and WSxM 4.0 Develop 11.1, Nanotec Electronica, TreaCantas, Spain).

\section{Data analysis}

Data were analyzed descriptively (mean and standard deviation), inferentially (paired Student's t or Wilcoxon tests), and by the F statistic (ANOVA) with Tukey's post-hoc or Tamhane's tests. The paired Student's $t$ test, Wilcoxon test for paired data, F statistic (ANOVA) with Tamhane's multiple comparisons or with Tukey's multiple comparisons were used in the MTT assay. The paired Student's t test, Wilcoxon test for paired data, and F statistic (ANOVA) with multiple comparisons were used for assessing neutral red uptake. Finally, Wilcoxon test for paired data, the Kruskal-Wallis test with paired comparisons and the Mann-Whitney test were used for the analysis of microhardness and degree of conversion. All the 
tests were performed using SPSS version 23 , and the level of significance was set at 0.05 .

\section{Results}

\section{Cytotoxic effect assessed by the MTT Assay}

Table 2 presents the mean, standard deviation, and coefficient of variation of the evaluated materials for their cytotoxic potential. The materials showed variable responses to cell metabolism. Low and/or no cytotoxic effect was observed for some of the tested resins in relation to time of evaluation and concentration of the extracts (1:2 and 1:10). Only Opus resin showed moderate cytotoxicity after 7 days at the $1: 2$ concentration. At $72 \mathrm{~h}$, all resins reduced the percentage of cell viability, except for Z350 and Z350F, when the concentration of the extracts was accounted for.

\section{Neutral red incorporation}

Table 3 presents the results for the neutral red incorporation test. After 7 days of evaluation, Opus, FBFS, FBFF, and ABF showed a lower percentage (92\%, $80 \%, 76 \%$, and $54 \%$, respectively) of cell viability at the 1:2 concentration.

Table 4 shows the statistical difference between extract concentrations according to each method of cytotoxicity analysis. The MTT assay revealed that only Opus, Z350 and XTF resins showed statistical differences between the extracts after $72 \mathrm{~h}$, without any difference verified for Z350 and XTF after 7 days. The neutral red test indicated statistically significant differences among most resins when the concentrations of the extracts were compared, especially after 7 days.

Table 2. Mean \pm standard deviation of MTT according to material, concentration, and days of evaluation.

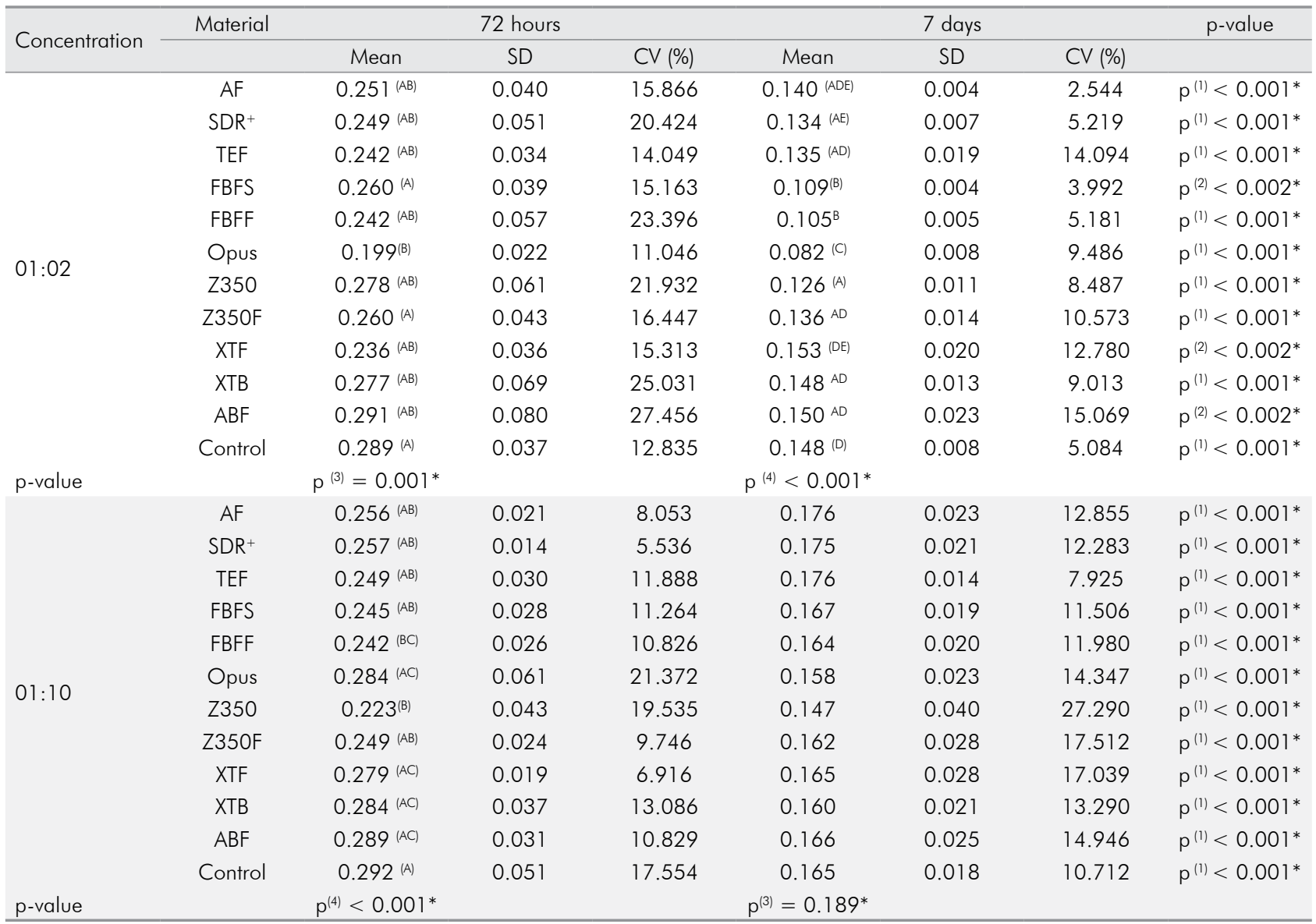

*Significant difference at 5\%; (1) by means of the paired Student's-t test; (2) by means of the Wilcoxon test for paired data. (3) By means of the F (ANOVA) with Tamhane's multiple comparisons; (4) by means of the F (ANOVA) with Tukey's multiple comparisons. Note: If all the letters in parentheses are different, there is significant difference between the corresponding materials. 
Table 3. Mean \pm standard deviation of neutral red according to material, concentration and days of evaluation.

\begin{tabular}{|c|c|c|c|c|c|c|c|c|}
\hline \multirow{2}{*}{ Concentration } & \multirow{2}{*}{ Material } & \multicolumn{3}{|c|}{72 hours } & \multicolumn{3}{|c|}{7 days } & \multirow[t]{2}{*}{$p$-value } \\
\hline & & Mean & SD & CV (\%) & Mean & SD & CV (\%) & \\
\hline \multirow{12}{*}{ 01:02 } & $A F$ & $0.466^{\text {(AD) }}$ & 0.034 & 7.350 & 0.251 (ACF) & 0.096 & 38.060 & $\mathrm{p}^{(1)}<0.001^{*}$ \\
\hline & $\mathrm{SDR}^{+}$ & 0.441 (AD) & 0.025 & 5.745 & 0.347 (ADF) & 0.102 & 29.453 & $\mathrm{p}^{(1)}<0.006^{*}$ \\
\hline & TEF & $0.488^{(\mathrm{A})}$ & 0.042 & 8.654 & $0.753^{(\mathbf{B})}$ & 0.135 & 17.981 & $\mathrm{p}^{(1)}<0.001^{*}$ \\
\hline & FBFS & $0.335^{(\mathbf{B})}$ & 0.063 & 18.666 & $0.171^{(\mathrm{CG})}$ & 0.063 & 36.652 & $\mathrm{p}^{(1)}<0.001^{*}$ \\
\hline & FBFF & $0.343^{(\mathbf{B})}$ & 0.057 & 16.634 & $0.168^{(\mathrm{CG})}$ & 0.054 & 32.119 & $\mathrm{p}^{(1)}<0.001^{*}$ \\
\hline & Opus & 0.262 (C) & 0.064 & 24.343 & $0.137^{(C)}$ & 0.079 & 57.592 & $\mathrm{p}^{(1)}<0.008^{*}$ \\
\hline & Z350 & $0.337^{(\mathbf{B})}$ & 0.055 & 16.223 & 0.424 (D) & 0.104 & 24.633 & $p^{(1)}=0.061$ \\
\hline & Z350F & $0.319^{(B C)}$ & 0.051 & 16.101 & 0.377 (AD) & 0.114 & 30.234 & $p^{(1)}=0.197$ \\
\hline & XTF & $0.456^{(A D)}$ & 0.048 & 10.415 & 0.284 (AEFG) & 0.066 & 23.146 & $\mathrm{p}^{(1)}<0.001^{*}$ \\
\hline & XTB & 0.459 (AD) & 0.039 & 8.417 & 0.285 (AEG) & 0.064 & 22.448 & $\mathrm{p}^{(1)}<0.001^{*}$ \\
\hline & $\mathrm{ABF}$ & 0.419 (AD) & 0.038 & & 0.243 (CFG) & 0.119 & 48.714 & $\mathrm{p}^{(1)}<0.001^{*}$ \\
\hline & Control & 0.451 (AD) & 0.058 & 12.808 & 0.384 (DE) & 0.085 & 22.225 & $p^{(1)}=0.108$ \\
\hline$p$-value & \multicolumn{3}{|c|}{$\mathrm{p}^{(3)}<0.001^{*}$} & \multicolumn{3}{|c|}{$\mathrm{p}^{(3)}<0001^{*}$} & & \\
\hline \multirow{12}{*}{$01: 10$} & $\mathrm{AF}$ & 0.423 (AFGI) & 0.034 & 8.084 & 0.381 (AE) & 0.063 & 16.414 & $\mathrm{p}^{(1)}<0.077^{*}$ \\
\hline & $\mathrm{SDR}^{+}$ & 0.445 (ABD) & 0.042 & 9.492 & 0.395 (AE) & 0.056 & 14.129 & $\mathrm{p}^{(1)}<0.020^{*}$ \\
\hline & TEF & $0.496^{\text {(BE) }}$ & 0.037 & 7.531 & 0.524 (AD) & 0.110 & 21.048 & $p^{(1)}=0.436$ \\
\hline & FBFS & $0.363(\mathrm{CHM})$ & 0.046 & 12.672 & 0.544 (BD) & 0.111 & 20.412 & $\mathrm{p}^{(1)}<0.001^{*}$ \\
\hline & FBFF & $0.369(\mathrm{ClO})$ & 0.026 & 6.933 & $0.391(\mathrm{AC})$ & 0.070 & 17.989 & $p^{(1)}=0.294$ \\
\hline & Opus & 0.334 (CJ) & 0.033 & 9.979 & $0.379(\mathrm{AC})$ & 0.088 & 23.175 & $p^{(1)}=0.107$ \\
\hline & Z350 & 0.399 (ADHI) & 0.039 & 9.706 & $0.412^{(\mathrm{ABC})}$ & 0.122 & 29.506 & $\mathrm{p}^{(1)}=0.723$ \\
\hline & Z350F & 0.373 (FHILL) & 0.049 & 13.109 & 0.337 (CE) & 0.085 & 25.110 & $\mathrm{p}^{(1)}=0.292$ \\
\hline & XTF & $0.425^{(\mathrm{ALG})}$ & 0.032 & 7.610 & 0.368 (CE) & 0.050 & 13.484 & $\mathrm{p}^{(1)}<0.015^{*}$ \\
\hline & XTB & 0.474 (CGMN) & 0.045 & 9.508 & $0.474(\mathrm{ABC})$ & 0.099 & 20.922 & $p^{(1)}=0.987$ \\
\hline & $\mathrm{ABF}$ & $0.382^{\text {(EFHO) }}$ & 0.044 & 11.465 & $0.323^{\text {(CE) }}$ & 0.105 & 32.477 & $p^{(1)}=0.129$ \\
\hline & Control & 0.432 (AEN) & 0.042 & 9.736 & 0.362 (CE) & 0.065 & 17.998 & $\mathrm{p}^{(1)}<0.015^{*}$ \\
\hline$p$-value & \multicolumn{3}{|c|}{$\mathrm{p}^{(3)}<0.001^{*}$} & \multicolumn{3}{|c|}{$\mathrm{p}^{(3)}<0.001^{*}$} & & \\
\hline
\end{tabular}

*Significant difference at 5\%; (1) by means of the paired Student's- $t$ test; (2) by means of the Wilcoxon test for paired data; by means of the F (ANOVA) with multiple comparisons. Note: If all the letters in parentheses are different, there is significant difference between the corresponding materials.

\section{Degree of conversion}

Table 5 shows the percentage degree of conversion according to thickness ( $2 \mathrm{~mm}$ and $4 \mathrm{~mm}$ ) and the analysis of surface morphology (top and bottom). The resins presented no significant difference in degree of conversion at $2 \mathrm{~mm}$ and $4 \mathrm{~mm}$. Statistically significant differences were observed only between materials.

\section{Vickers hardness}

Microhardness values are listed in Table 6. The lowest microhardness values were observed for FBFF, Opus, and TEF resins, while the highest ones were obtained for XTF and Z350. No statistical difference was observed regarding the surface subjected to polymerization, but statistically significant differences were found when the thickness of the test specimens was compared.

\section{Surface morphology (SEM/AFM) and EDS analyses}

SEM images showed surfaces with deep scratches, detachment, and protrusion of load particles. The AFM analysis revealed depressions, protrusions, and irregular surfaces with deep scratches in most resins. TEF, Opus, and XTF resins presented uniform and slightly scratched surfaces with homogeneous surface topography (Figure).

Table 7 presents the chemical composition and the respective percentages of inorganic components for the resins evaluated by EDS. Most resins contained $\mathrm{Si}$, followed by $\mathrm{Ba}, \mathrm{Zr}$, and Al. Zirconia and silica peaks corresponded to the zirconia-silica clusters or to the silicate particles found in the composite resins. Ba could represent the barium-silicate particles added to ensure radiopacity. 
Table 4. Statistical analysis of cytotoxicity of the materials with comparison of extract concentrations, according to each test.

\begin{tabular}{|c|c|c|c|c|}
\hline \multirow{3}{*}{ Variable } & \multicolumn{4}{|c|}{$p$-value } \\
\hline & \multicolumn{2}{|c|}{ MTT } & \multicolumn{2}{|c|}{ NR } \\
\hline & $72 \mathrm{~h} \neq 1: 2$ and $1: 10$ & $7 D \neq 1: 2$ and $1: 10$ & $72 \mathrm{~h} \neq 1: 2$ and $1: 10$ & $7 D \neq 1: 2$ and $1: 10$ \\
\hline $\mathrm{AF}$ & $p^{(1)}=0.677$ & $\mathrm{p}^{(2)}<0.001^{*}$ & $\mathrm{p}^{(1)}=0.005^{*}$ & $\mathrm{p}^{(1)}=0.001^{*}$ \\
\hline $\mathrm{SDR}^{+}$ & $p^{(2)}=0.624$ & $\mathrm{p}^{(2)}<0.001^{*}$ & $p^{(1)}=0.773$ & $p^{(1)}=0.168$ \\
\hline TEF & $p^{(1)}=0.575$ & $\mathrm{p}^{(1)}<0.001^{*}$ & $p^{(1)}=0.631$ & $\mathrm{p}^{(1)}<0.001^{*}$ \\
\hline FBFS & $p^{(2)}=0.293$ & $\mathrm{p}^{(2)}<0.001^{*}$ & $p^{(1)}=0.240$ & $\mathrm{p}^{(1)}<0.001^{*}$ \\
\hline FBFF & $p^{(1)}=0.980$ & $\mathrm{p}^{(2)}<0.001^{*}$ & $p^{(2)}=0.165$ & $\mathrm{p}^{(1)}<0.001^{*}$ \\
\hline Opus & $\mathrm{p}^{(2)}<0.001^{*}$ & $\mathrm{p}^{(2)}<0.001^{*}$ & $\mathrm{p}^{(1)}<0.002^{*}$ & $\mathrm{p}^{(1)}<0.001^{*}$ \\
\hline Z350 & $\mathrm{p}^{(1)}<0.018^{*}$ & $p^{(2)}=0.097$ & $\mathrm{p}^{(1)}<0.004^{*}$ & $p^{(1)}=0.807$ \\
\hline Z350F & $p^{(1)}=0.460$ & $\mathrm{p}^{(1)}<0.008^{*}$ & $\mathrm{p}^{(1)}<0.015^{*}$ & $p^{(1)}=0.338$ \\
\hline XTF & $\mathrm{p}^{(1)}<0.002^{*}$ & $p^{(1)}=0.239$ & $p^{(1)}=0.069$ & $\mathrm{p}^{(1)}<0.002^{*}$ \\
\hline XTB & $p^{(1)}=0.757$ & $p^{(1)}=0.124$ & $p^{(1)}=0.386$ & $\mathrm{p}^{(1)}<0.001^{*}$ \\
\hline $\mathrm{ABF}$ & $p^{(2)}=0.922$ & $p^{(1)}=0.122$ & $\mathrm{p}^{(1)}<0.037^{*}$ & $p^{(1)}=0.096$ \\
\hline Control & $p^{(1)}=0.888$ & $\mathrm{p}^{(2)}<0.007^{*}$ & $p^{(1)}=0.367$ & $p^{(1)}=0.495$ \\
\hline
\end{tabular}

*Significant difference at 5\%; (1) by means of the Student's-t test with equal variances for comparison between the concentrations per evaluation and material; (2) by means of the Student's-t test with unequal variances for comparison between the concentrations per evaluation and material.

Table 5. Mean \pm standard deviation of degree of conversion according to material and thickness, and the surface of the test specimen subjected to polymerization.

\begin{tabular}{|c|c|c|c|c|c|c|c|c|}
\hline \multirow{2}{*}{ Thickness } & \multirow{2}{*}{ Material } & \multicolumn{3}{|c|}{ Top } & \multicolumn{3}{|c|}{ Bottom } & \multirow[t]{2}{*}{$p$-value } \\
\hline & & Mean & SD & CV (\%) & Mean & SD & CV (\%) & \\
\hline \multirow{11}{*}{$2 \mathrm{~mm}$} & $\mathrm{AF}$ & $93.97^{(\mathrm{A})}$ & 2.35 & 2.50 & $89.07^{(A)}$ & 3.79 & 4.25 & $p^{(1)}=0.250$ \\
\hline & $A B F$ & $73.23^{(\mathrm{BEG})}$ & 14.68 & 20.05 & 70.07 (BE) & 1.86 & 2.65 & $\mathrm{p}^{(1)}=0.750$ \\
\hline & FBFS & 82.10 (ABEH) & 16.31 & 19.86 & $56.60(\mathrm{C})$ & 3.30 & 5.84 & $\mathrm{p}^{(1)}=0.250$ \\
\hline & $\mathrm{SDR}^{+}$ & $86.50^{(A B)}$ & 1.84 & 2.12 & $80.57^{(A B)}$ & 10.32 & 12.80 & $\mathrm{p}^{(1)}=1.000$ \\
\hline & TEF & $62.93(\mathrm{CD})$ & 5.63 & 8.95 & $65.70^{(\mathrm{EF})}$ & 0.56 & 0.85 & $\mathrm{p}^{(1)}=0.750$ \\
\hline & Opus & $75.33^{(B F)}$ & 1.50 & 1.99 & $41.43^{(\mathrm{D})}$ & 10.21 & 24.63 & $\mathrm{p}^{(1)}=0.250$ \\
\hline & XTB & 74.10 (CEI) & 0.50 & 0.67 & $71.03^{(A B)}$ & 1.25 & 1.76 & $p^{(1)}=0.250$ \\
\hline & XTF & $76.77^{\text {(BEF) }}$ & 6.26 & 8.16 & $56.50^{(\mathrm{CG})}$ & 5.08 & 8.98 & $p^{(1)}=0.250$ \\
\hline & Z350 & 65.83 (CEG) & 1.57 & 2.38 & 46.67 (D) & 8.97 & 19.23 & $\mathrm{p}^{(1)}=0.250$ \\
\hline & Z350F & $55.63^{(D)}$ & 0.35 & 0.63 & 57.27 (CF) & 1.21 & 2.11 & $\mathrm{p}^{(1)}=0.500$ \\
\hline & FBFF & 72.00 (CFGHI) & 5.91 & 8.21 & $45.27(\mathrm{DG})$ & 1.80 & 3.98 & $\mathrm{p}^{(1)}=0.250$ \\
\hline \multirow[t]{6}{*}{$\mathrm{p}$-value } & & $\mathrm{p}^{(2)}=0.009^{*}$ & & & $\mathrm{p}^{(2)}=0.001^{*}$ & & & \\
\hline & $\mathrm{AF}$ & 99.07 (A) & 0.51 & 0.52 & 58.97 (ACGH) & 15.33 & 26.00 & $\mathrm{p}^{(1)}=0.250$ \\
\hline & $A B F$ & $77.10^{(B)}$ & 1.08 & 1.40 & $20.70^{(\mathrm{B})}$ & 7.19 & 34.75 & $\mathrm{p}^{(1)}=0.250$ \\
\hline & FBFS & $98.00(\mathrm{AC})$ & 0.20 & 0.20 & $56.17(A B)$ & 2.01 & 3.58 & $p^{(1)}=0.250$ \\
\hline & $\mathrm{SDR}^{+}$ & 85.97 (BD) & 1.74 & 2.02 & 66.70 (CEIJ) & 1.84 & 2.75 & $\mathrm{p}^{(1)}=0.250$ \\
\hline & TEF & 74.30 (E) & 1.22 & 1.64 & 64.33 (ACI) & 2.14 & 3.32 & $\mathrm{p}^{(1)}=0.250$ \\
\hline \multirow[t]{6}{*}{$4 \mathrm{~mm}$} & Opus & $72.20^{(\mathrm{E})}$ & 4.33 & 5.99 & 67.13 (СDELI) & 2.60 & 3.87 & $\mathrm{p}^{(1)}=0.250$ \\
\hline & XTB & $75.00^{(E)}$ & 0.40 & 0.53 & $68.77^{(\mathrm{FI})}$ & 1.83 & 2.67 & $p^{(1)}=0.250$ \\
\hline & XTF & $90.50(\mathrm{CD})$ & 3.31 & 3.65 & $75.37^{(\mathrm{FL})}$ & 2.75 & 3.65 & $\mathrm{p}^{(1)}=0.250$ \\
\hline & Z350 & $64.60^{(F)}$ & 1.35 & 2.09 & 58.73 (АМJ) & 2.96 & 5.03 & $\mathrm{p}^{(1)}=0.250$ \\
\hline & $\mathrm{Z} 350 \mathrm{~F}$ & $57.33^{(F)}$ & 0.91 & 1.58 & 54.77 (BGM) & 0.50 & 0.92 & $\mathrm{p}^{(1)}=0.250$ \\
\hline & FBFF & $72.30^{(E)}$ & 4.22 & 5.84 & $67.53^{(\mathrm{HIL})}$ & 1.80 & 2.67 & $p^{(1)}=0.250$ \\
\hline \multirow[t]{5}{*}{$\mathrm{p}$-value } & & $\mathrm{p}^{(2)}=0.001^{*}$ & & & $\mathrm{p}^{(2)}=0.008^{*}$ & & & \\
\hline & $\mathrm{AF}$ & $\mathrm{p}^{(3)}=0.100$ & & & $\mathrm{p}^{(3)}=0.100$ & & & \\
\hline & $A B F$ & $\mathrm{p}^{(3)}=0.800$ & & & $\mathrm{p}^{(3)}=0.100$ & & & \\
\hline & FBFS & $\mathrm{p}^{(3)}=0.400$ & & & $p^{(3)}=1.000$ & & & \\
\hline & $\mathrm{SDR}^{+}$ & $p^{(3)}=1.000$ & & & $\mathrm{p}^{(3)}=0.200$ & & & \\
\hline \multirow{7}{*}{$\begin{array}{l}\mathrm{p} \text {-value- } \neq 2 \\
\text { and } 4 \mathrm{~mm}\end{array}$} & TEF & $\mathrm{p}^{(3)}=0.100$ & & & $\mathrm{p}^{(3)}=0.400$ & & & \\
\hline & Opus & $\mathrm{p}^{(3)}=0.700$ & & & $\mathrm{p}^{(3)}=0.100$ & & & \\
\hline & XTB & $\mathrm{p}^{(3)}=0.200$ & & & $\mathrm{p}^{(3)}=0.200$ & & & \\
\hline & XTF & $\mathrm{p}^{(3)}=0.100$ & & & $\mathrm{p}^{(3)}=0.100$ & & & \\
\hline & Z350 & $\mathrm{p}^{(3)}=0.700$ & & & $\mathrm{p}^{(3)}=0.100$ & & & \\
\hline & $\mathrm{Z} 350 \mathrm{~F}$ & $\mathrm{p}^{(3)}=0.100$ & & & $\mathrm{p}^{(3)}=0.100$ & & & \\
\hline & FBFF & $\mathrm{p}^{(3)}=1.000$ & & & $\mathrm{p}^{(3)}=0.100$ & & & \\
\hline
\end{tabular}

*Significant difference at 5\% (1) By means of the Wilcoxon test for paired data. (2) By means of the Kruskal-Wallis test with paired comparisons of the mentioned test. (3) By means of the Mann-Whitney test. Note: If all the letters in parentheses are different, there is significant difference between the corresponding materials. 
Physicomechanical characterization and biological evaluation of bulk-fill composite resin

Table 6. Mean \pm standard deviation of microhardness according to material, thickness, and surface of the test specimen subjected to polymerization.

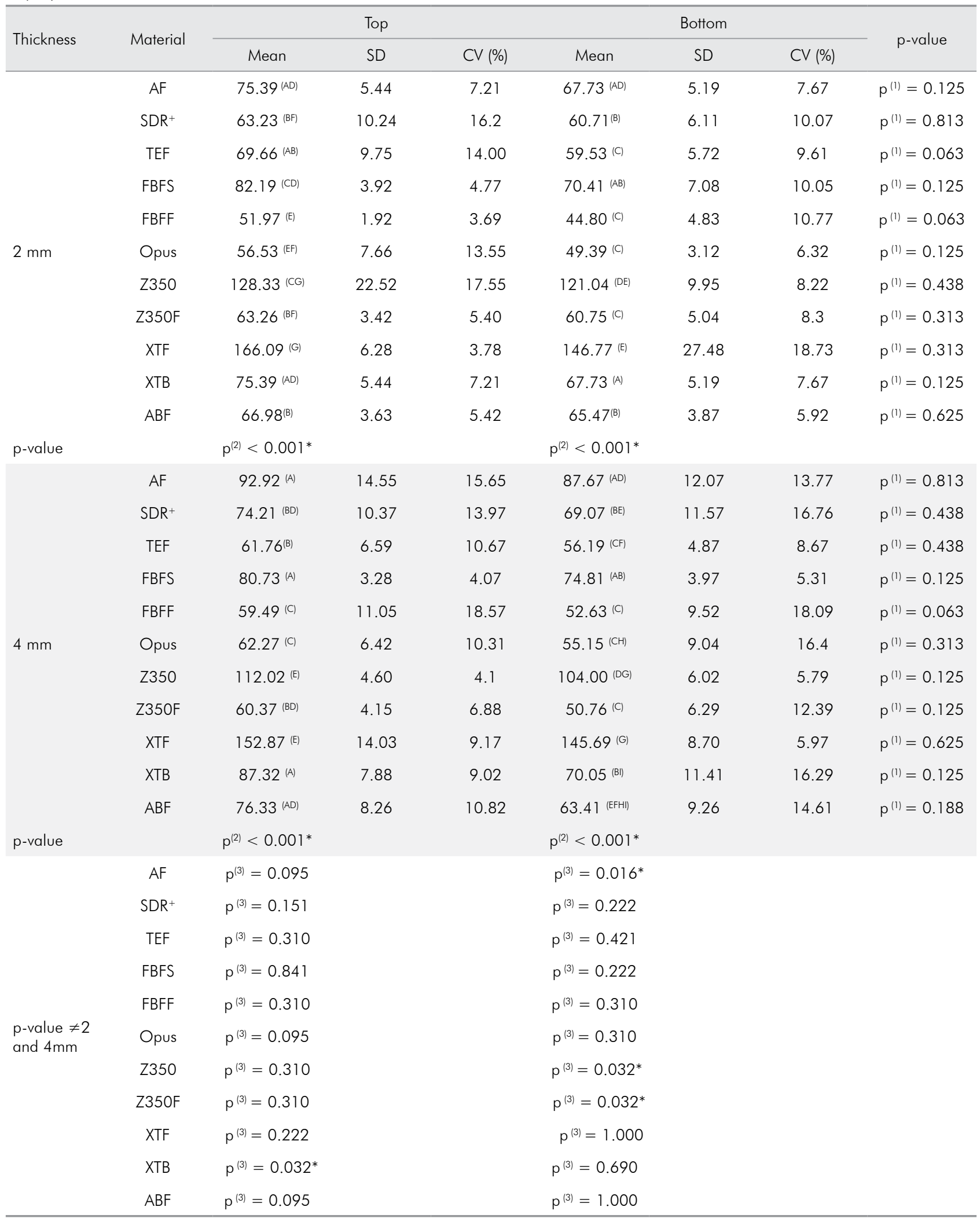

*Significant difference at 5\%; (1) by means of the Wilcoxon test for paired data; (3) by means of the Kruskal-Wallis test with paired comparisons of the mentioned test. Note: If all the letters in parentheses are different, there is significant difference between the corresponding materials. 

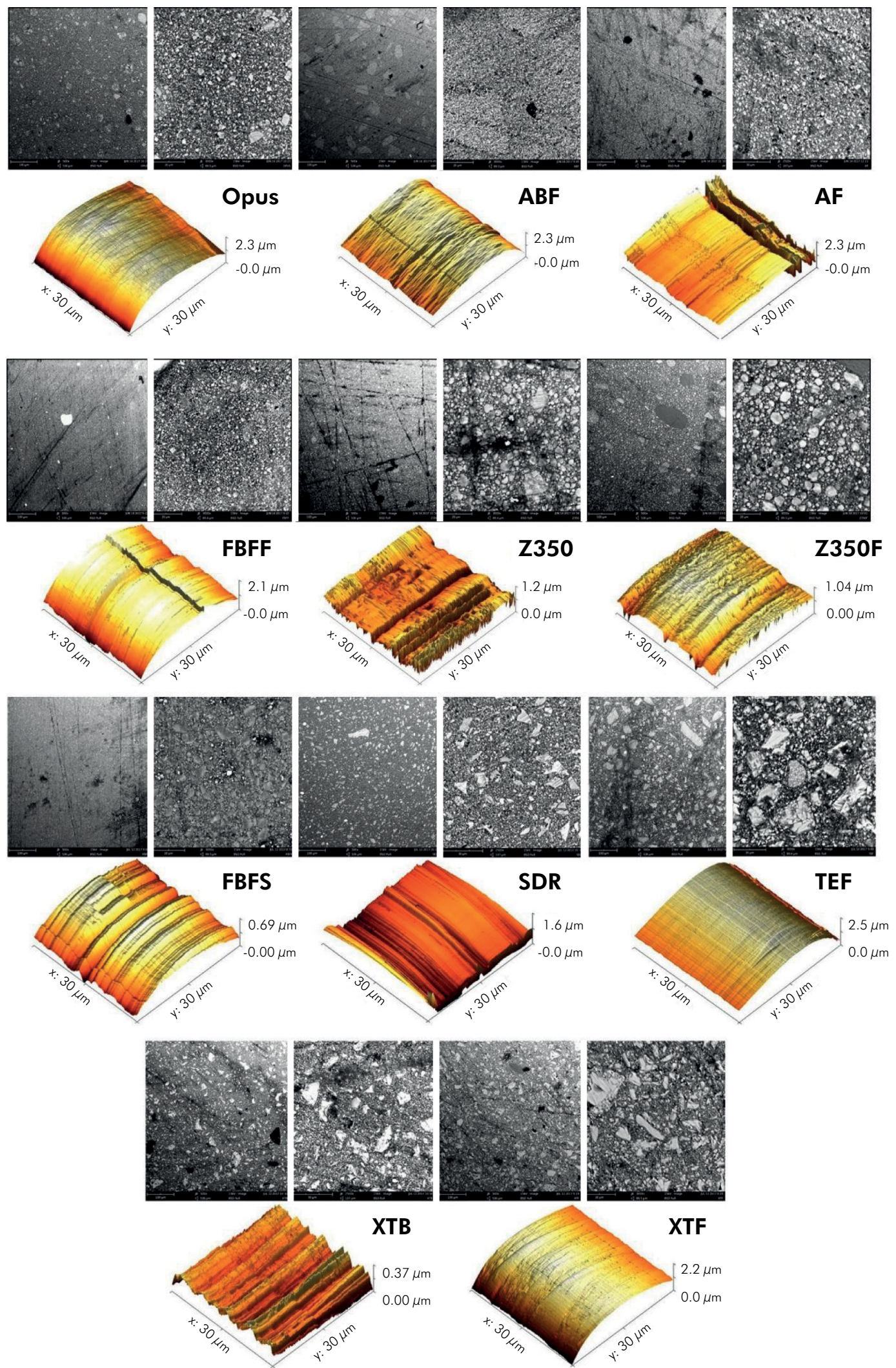

Figure 1. Image representative of the surface morphology (SEM/AFM) of the materials after finishing and polishing with soft-lex discs. SEM images at 500 and 3000X magnification. 
- Physicomechanical characterization and biological evaluation of bulk-fill composite resin

Table 7. Chemical elements identified by means of EDS analysis (\% and SD).

\begin{tabular}{|c|c|c|c|c|c|c|c|c|c|c|c|}
\hline \multirow{2}{*}{$\begin{array}{l}\text { Chemical } \\
\text { elements (\%) } \\
\pm \text { SD }\end{array}$} & \multicolumn{11}{|c|}{ Composite resin } \\
\hline & $\mathrm{ABF}$ & FBFF & FBFS & $\mathrm{AF}$ & $\mathrm{SDR}^{+}$ & TEF & XTF & XTB & Opus & Z350F & Z350 \\
\hline $\mathrm{Al}$ & $\begin{array}{c}10.8 \pm \\
0.051\end{array}$ & $\begin{array}{c}4.05 \pm \\
0.044\end{array}$ & $\begin{array}{l}7.2 \pm \\
0.036\end{array}$ & $\begin{array}{c}10.7 \pm \\
0.048\end{array}$ & $\begin{array}{c}12.6 \pm \\
0.047\end{array}$ & $\begin{array}{c}14.6 \pm \\
0.065\end{array}$ & $\begin{array}{c}11.7 \pm \\
0.054\end{array}$ & $\begin{array}{c}14.0 \pm \\
0.064\end{array}$ & $\begin{array}{c}6.35 \pm \\
0.07\end{array}$ & $\begin{array}{c}3.01 \pm \\
0.035\end{array}$ & $\begin{array}{r}1.47 \pm \\
0.028\end{array}$ \\
\hline $\mathrm{Si}$ & $\begin{array}{c}61.2 \pm \\
0.075\end{array}$ & $\begin{array}{c}49.4 \pm \\
0.059\end{array}$ & $\begin{array}{c}44.9 \pm \\
0.054\end{array}$ & $\begin{array}{c}65.1 \pm \\
0.074\end{array}$ & $\begin{array}{c}47.0 \pm \\
0.059\end{array}$ & $\begin{array}{c}48.1 \pm \\
0.073\end{array}$ & $\begin{array}{c}55.1 \pm \\
0.074\end{array}$ & $\begin{array}{c}50.7 \pm \\
0.073\end{array}$ & $\begin{array}{c}24.06 \pm \\
0.09\end{array}$ & $\begin{array}{c}57.5 \pm \\
0.060\end{array}$ & $\begin{array}{r}55.7 \pm \\
0.053\end{array}$ \\
\hline $\mathrm{Ca}$ & $\begin{array}{c}0.29 \pm \\
0.004\end{array}$ & $\begin{array}{c}0.08 \pm \\
0.003\end{array}$ & - & - & $\begin{array}{c}0.08 \pm \\
0.003\end{array}$ & - & - & - & $\begin{array}{c}1.21 \pm \\
0.013\end{array}$ & - & - \\
\hline $\mathrm{Ba}$ & $\begin{array}{c}26.9 \pm \\
0.055\end{array}$ & - & $\begin{array}{c}8.7 \pm \\
0.07\end{array}$ & $\begin{array}{c}23.8 \pm \\
0.05\end{array}$ & $\begin{array}{c}19.3 \pm \\
0.086\end{array}$ & $\begin{array}{c}28.0 \pm \\
0.059\end{array}$ & $\begin{array}{c}31.1 \pm \\
0.062\end{array}$ & $\begin{array}{c}28.6 \pm \\
0.066\end{array}$ & $\begin{array}{c}26.15 \pm \\
0.022\end{array}$ & $\begin{array}{c}0.58 \pm \\
0.020\end{array}$ & - \\
\hline $\mathrm{Cu}$ & $\begin{array}{c}0.015 \pm \\
0.001\end{array}$ & - & - & $\begin{array}{c}0.015 \pm \\
0.001\end{array}$ & - & - & $\begin{array}{c}0.02 \pm \\
0.001\end{array}$ & - & - & - & - \\
\hline $\mathrm{Sr}$ & $\begin{array}{c}0.26 \pm \\
0.001\end{array}$ & - & $\begin{array}{l}2.8 \pm \\
0.007\end{array}$ & $\begin{array}{c}0.24 \pm \\
0.001\end{array}$ & $\begin{array}{c}19.3 \pm \\
0.017\end{array}$ & $\begin{array}{c}0.29 \pm \\
0.001\end{array}$ & $\begin{array}{c}0.42 \pm \\
0.001\end{array}$ & $\begin{array}{c}0.35 \pm \\
0.002\end{array}$ & - & $\begin{array}{c}0.06 \pm \\
0.001\end{array}$ & - \\
\hline Y & $\begin{array}{c}0.08 \pm \\
0.001\end{array}$ & - & $\begin{array}{c}0.10 \pm \\
0.002\end{array}$ & - & - & - & - & - & - & $\begin{array}{c}0.03 \pm \\
0.001\end{array}$ & $\begin{array}{r}0.15 \pm \\
0.002\end{array}$ \\
\hline $\mathrm{Zr}$ & $\begin{array}{c}0.08 \pm \\
0.001\end{array}$ & $\begin{array}{c}18.0 \pm \\
0,017\end{array}$ & $\begin{array}{c}22.6 \pm \\
0.022\end{array}$ & - & - & - & $\begin{array}{c}0.06 \pm \\
0.001\end{array}$ & - & - & $\begin{array}{c}13.1 \pm \\
0.012\end{array}$ & $\begin{array}{r}17.9 \pm \\
0.015\end{array}$ \\
\hline$P$ & $\begin{array}{c}0.38 \pm \\
0.010\end{array}$ & $\begin{array}{c}21.7 \pm \\
0,041\end{array}$ & $\begin{array}{l}8.8 \pm \\
0.025\end{array}$ & - & $\begin{array}{c}1.63 \pm \\
0.018\end{array}$ & - & - & - & - & $\begin{array}{c}22.0 \pm \\
0.041\end{array}$ & $\begin{array}{r}24.2 \pm \\
0.038\end{array}$ \\
\hline $\mathrm{Ti}$ & - & - & - & - & - & - & - & - & - & - & $\begin{array}{c}0.20 \pm \\
0.011\end{array}$ \\
\hline $\mathrm{Yb}$ & - & $\begin{array}{l}6.5 \pm \\
0.021\end{array}$ & $\begin{array}{l}4.6 \pm \\
0.022\end{array}$ & - & - & $\begin{array}{c}8.48 \pm \\
0.018\end{array}$ & - & $\begin{array}{c}6.18 \pm \\
0.017\end{array}$ & - & $\begin{array}{c}3.26 \pm \\
0.014\end{array}$ & - \\
\hline $\mathrm{Hf}$ & - & $\begin{array}{c}0.26 \pm \\
0.005\end{array}$ & $\begin{array}{c}0.27 \pm \\
0.006\end{array}$ & - & - & - & - & - & - & $\begin{array}{c}0.26 \pm \\
0.004\end{array}$ & $\begin{array}{r}0.35 \pm \\
0.005\end{array}$ \\
\hline$S$ & - & - & - & $\begin{array}{c}0.11 \pm \\
0.004\end{array}$ & $\begin{array}{c}0.08 \pm \\
0.004\end{array}$ & $\begin{array}{c}0.44 \pm \\
0.006\end{array}$ & $\begin{array}{l}1.50 \pm \\
0.009\end{array}$ & $\begin{array}{c}0.08 \pm \\
0.004\end{array}$ & - & - & - \\
\hline
\end{tabular}

\section{Discussion}

The results of this study led to the rejection of the first null hypothesis. In the MTT assay, there was a greater decrease in cell viability at the 1:2 than at the 1:10 concentration, and the materials showed a slight cytotoxic potential in relation to the control, except for Opus $(1: 2-72 \mathrm{~h}) .{ }^{11}$ Low cytotoxicity levels detected by MTT in pulp cells were also reported by Marigo et al. ${ }^{12}$

The cytotoxicity of these materials has been associated with the amount and type of residual monomer released, demonstrating a correlation between this phenomenon and mass loss and/or low degree of conversion. ${ }^{13}$ Even though composite resins are considered to be biologically well tolerated, there have been some reports of allergic effects on oral mucosal tissues, ${ }^{3}$ due to the dissolution of methacrylate and to the leaching of its components. ${ }^{4}$ All the materials presented acceptable cytotoxic potential at the thickness of $4 \mathrm{~mm}$; however, Opus did not fit into these standards, corroborating the results of Jang et al., ${ }^{14}$ who affirmed that not all bulk-fill resins achieve proper polymerization at this thickness. According to the neutral red test, cell viability decreased as exposure time increased from $72 \mathrm{~h}$ to 7 days, especially for the bulk-fill flowable resins, except for TEF. This indicates that the components of the resins are continuously released after polymerization, corroborating the findings of Karaarslan et al. ${ }^{15}$ On the other hand, Yildirin-Bicer et al. ${ }^{16}$ reported that the 24-hour exposure period proved to be the most cytotoxic one. Tsitrou et al., ${ }^{17}$ however, reported that the time, solution, and type of material used significantly influence the detection of residual monomer and cytotoxicity. ${ }^{18}$ In this study, an aqueous medium was used by means of the direct technique, which may have favored the dissolution of hydrophilic and low molecular weight monomers.

The release of monomers, especially methacrylatebased ones (Bis-GMA, Bis-EMA, UDMA), co-monomers (TEGDMA and HEMA), and some composite additives, 
causes local adverse effects (pulp changes, marginal gingivitis, and allergic reactions) and even systemic effects, with allergic, ${ }^{19}$ cytotoxic, ${ }^{20}$ genotoxic, and toxic potential on the reproductive system. ${ }^{21}$ The exact mechanism by which this occurs has not yet been established in the literature; however, the reduction in cellular glutathione level $\mathrm{s}^{22}$ and the increase in the levels of reactive oxygen species (ROS) are believed to be the main triggers; ${ }^{23}$ in addition, the latter has been associated with damage to cellular DNA exposed to methacrylate. ${ }^{24}$ On the other hand, Tauböck et al. ${ }^{5}$ reported that the tested bulk-fill resins did not induce significant genotoxic effects on cellular DNA.

The second hypothesis, which posited that there would be no difference between the methods used for evaluating cytotoxicity, was also rejected. The neutral red test was more sensitive than MTT regarding time and concentration of the extracts. The neutral red test was directly associated with lysosomal membrane integrity, ${ }^{25}$ while the MTT assay was associated with mitochondrial integrity. ${ }^{26,27}$ Based on the results, the authors concluded that the toxic effect of resins at the lysosomal level precedes the effect on the mitochondria. Lysosomes participate in the apoptotic process if it is initiated by the rupture of this organelle from an exogenous stimulus, which leads to the release of lysosomal enzymes into the cellular cytoplasm, triggering a cascade of intracellular degradation events. These enzymes may directly attack the mitochondria and induce the release of cytochrome c, increase the formation of mitochondrial reactive oxygen species, and activate pro-apoptotic proteins. ${ }^{28}$ This shows that neutral red could be an important tool in the detection of initial damage at the lysosomal level, distinguish the cytotoxic effects at the cellular level from the damage to cellular organelles, and explain the different results obtained by the two methods in this study.

Notwithstanding, the neutral red test is dependent on the number of viable cells and on the lysosomal viability of cells or their function. Thus, the simultaneous use of different evaluation methods reinforces the obtained results and provides information about the possible mechanism of action of the toxin. According to Fotakis, ${ }^{29}$ neutral red and MTT assays were more sensitive than the LDH and total protein tests for the detection of cytotoxicity.
The third null hypothesis, dealing with the degree of conversion and microhardness, was partially rejected, since a significant difference was found between the thicknesses of the specimens in the microhardness test. Marigo et al. ${ }^{12}$ also found a statistically significant difference between the thicknesses of the test specimens ( $2 \mathrm{~mm}$ and $4 \mathrm{~mm}$ ), corroborating the findings of this study obtained the for microhardness test. Bulk-fill flowable resins presented lower microhardness when compared to restorative resins, but the difference was not statistically significant. Similar results were obtained by Flury et al. ${ }^{30}$ and by Garoushi et al. ${ }^{31}$ The low percentage values for load particles of the flowable composite resins may explain the data obtained. Thus, in order for these materials to withstand the conditions of the oral cavity, it is necessary to coat them with a conventional resin. ${ }^{31}$ Among flowable resins, XTB presented better VH than the other materials, which suggests that the data obtained are related to the load content of each material (manufacturer's information), thus corroborating the findings of Zorzin et al. ${ }^{32}$ and of Ashali et al. ${ }^{33}$ The data obtained in this work did not reveal a significant reduction in microhardness on the polymerization surface, indicating adequate monomer conversion. Similar results were reported by Tauböck et al. ${ }^{5}$ As regards the degree of conversion, no influence of the thickness and surface subjected to polymerization was observed. Degree of conversion at the top and bottom of all resin specimens was greater than the clinically recommended values (> 55\%), according to Alshali et al., ${ }^{34}$ except for AFB (4 mm) Z350F, Opus, and FBFF (2 mm) at the bottom. Other authors ${ }^{31,6}$ also obtained a good degree of conversion at $4 \mathrm{~mm}$ for bulk-fill resins. Higher translucency, modifications in the photoinitiator system, and incorporation of charge particles that function as "microscopic springs" into bulk-fill resins, compared to the conventional ones used in these studies (Z350 and Z350F), may explain the higher degree of conversion. This allows greater penetrability of the photopolymerizing light, thereby increasing the depth of cure. ${ }^{5}$ However, ABF presented low degree of conversion on the bottom surface at $4 \mathrm{~mm}(20 \%)$, without statistical significance, drawing attention 
to the influence of the material on the varied results obtained. ${ }^{35}$ Statistical differences were observed among the evaluated materials, as expected, since degree of conversion is influenced by variables such as composite type, monomer composition, inorganic fraction, mass viscosity, reaction temperature, thickness of the increment, among others. ${ }^{36}$ It should be noted that degree of conversion differs from degree of polymerization. The former refers to the percentage of conversion of carbon-carbon bonds into single bonds, while the latter corresponds to the quality of the formed polymer network in terms of chain size and is defined by the ratio between the molecular weight of the polymer and the molecular weight of the repeating polymer units. Regarding surface morphology, SEM and AFM images showed rough surfaces after the finishing and polishing with Sof-Lex discs. According to Sahbaz et al. ${ }^{37}$ the use of Sof-Lex discs results in good finishing and polishing levels compared to other systems. Thus, the irregularities presented by most of the resins in this study may have been due to the displacement of load particles, which produced surface grooves when combined with the use of a rotary instrument. Clinically, increased roughness directly influences restoration esthetics, secondary caries, and patients' periodontal health, the latter of which is associated with biofilm accumulation. ${ }^{38}$ These results show the importance of this evaluation, given that five resins

\section{References}

1. Moharamzadeh K, Brook IM, Scutt AM, Thornhill MH, Van Noort R. Mucotoxicity of dental composite resins on a tissue-engineered human oral mucosal model. J Dent. 2008 May;36(5):331-6. https://doi.org/10.1016/i.jdent.2008.01.019

2. Salehi S, Gwinner F, Mitchell JC, Pfeifer C, Ferracane JL. Cytotoxicity of resin composites containing bioactive glass fillers. Dent Mater. 2015 Feb;31(2):195-203. https://doi.org/10.1016/j.dental.2014.12.004

3. Sevkusic M, Schuster L, Rothmund L, Dettinger K, Maier M, Hickel $R$ et al. The elution and breakdown behavior of constituents from various light-cured composites. Dent Mater. 2014 Jun;30(6):61931. https://doi.org/10.1016/i.dental.2014.02.022

4. Darmani H, Al-Hiyasat AS, Milhem MM. Cytotoxicity of dental composites and their leached components. Quintessence Int. 2007 Oct;38(9):789-95.
(ABF, FBFF, Opus, TEF, and XTF) had greater Ra values than those clinically acceptable $(0.2 \mu \mathrm{m})$ for the enamel. Note that, although previous studies indicate that the Sof-Lex disc had good finishing/ polishing outcomes, there is no universal system to perform such procedure in all resins. The indication and final outcomes produced by each system depend on the hardness, size, and content of load particles. ${ }^{39}$

\section{Conclusion}

Bulk-fill resins exhibited low and/or no cytotoxicity to L929 cells, except for Opus, which had moderate cytotoxicity, as pointed out by the MTT assay. However, when the neutral red test was used, results were not satisfactory for all composites, showing the need to use different methodologies to evaluate the properties of these materials. Yet, the resins presented acceptable values for microhardness, degree of conversion, and surface morphology.

\section{Acknowledgements}

The authors wish to thank Mr. João Batista Morais dos Santos for the technical assistance with the microhardness measurements and the Federal University of Campina Grande (UFCG) for technical support.

5. Tauböck TT, Marovic D, Zeljezic D, Steingruber AD, Attin T, Tarle Z. Genotoxic potential of dental bulk-fill resin composites. Dent Mater. 2017 Jul;33(7):788-95. https://doi.org/10.1016/i.dental.2017.04.011

6. Marovic D, Tauböck TT, Attin T, Panduric V, Tarle Z. Monomer conversion and shrinkage force kinetics of low-viscosity bulk-fill resin composites. Acta Odontol Scand. 2015 Aug;73(6):474-80. https://doi.org/10.3109/00016357.2014.992810

7. Benetti AR, Havndrup-Pedersen C, Honoré D, Pedersen MK, Pallesen U. Bulk-fill resin composites: polymerization contraction, depth of cure, and gap formation. Oper Dent. 2015 Mar-Apr;40(2):190-200. https://doi.org/10.2341/13-324-L 
8. Furness A, Tadros MY, Looney SW, Rueggeberg FA. Effect of bulk/incremental fill on internal gap formation of bulk-fill composites. J Dent. 2014 Apr;42(4):439-49. https://doi.org/10.1016/i.jdent.2014.01.005

9. Jan YD, Lee BS, Lin CP, Tseng WY. Biocompatibility and cytotoxicity of two novel low-shrinkage dental resin matrices. J Formos Med Assoc. 2014 Jun;113(6):349-55. https://doi.org/10.1016/j.jfma.2012.07.008

10. International Organization for Standardization - ISO. ISO 10993-5:2009: Biological evaluation of medical devices. Part 5: Tests for in vitro cytotoxicity. Geneve: International Organization for Standardization; 2009.

11. Toh WS, Yap AU, Lim SY. In vitro biocompatibility of contemporary bulkfill composites. Oper Dent. 2015 Nov-Dec;40(6):644-52. https://doi.org/10.2341/15-059-L

12. Marigo L, Spagnuolo G, Malara F, Martorana GE, Cordaro $M$, Lupi $A$ et al. Relation between conversion degree and cytotoxicity of a flowable bulk-fill and three conventional flowable resin-composites. Eur Rev Med Pharmacol Sci. 2015 Dec;19(23):4469-80.

13. Ahmed RH, Aref MI, Hassan RM, Mohammed NR. Cytotoxic effect of composite resin and amalgam filling materials on human labial and buccal epithelium. Nat Sci. 2010;8(10):48-53.

14. Jang JH, Park SH, Hwang IN. Polymerization shrinkage and depth of cure of bulk-fill resin composites and highly filled flowable resin. Oper Dent. 2015 Mar-Apr;40(2):172-80. https://doi.org/10.2341/13-307-L

15. Karaarslan ES, Altintas S, Bulbul M, Cebe MA, Usumez A. High performance liquid chromatography analysis of monomers from one composite resin cured with different polymerization methods. Mater Res Innov. 2011 Nov;15(2):1249. https://doi.org/10.1179/143307511X12998222918912

16. Yildirim-Bicer AZ, Ergun G, Egilmez F, Demirkoprulu $H$. In vitro cytotoxicity of indirect composite resins: effect of storing in artificial saliva. Indian J Dent Res. 2013 JanFeb;24(1):81-6. https://doi.org/10.4103/0970-9290.114962

17. Tsitrou E, Kelogrigoris S, Koulaouzidou E, AntoniadesHalvatioglou M, Koliniotou-Koumpia E, van Noort R. Effect of extraction media and storage time on the elution of monomers from four contemporary resin composite materials. Toxicol Int. 2014 Jan;21(1):89-95. https://doi.org/10.4103/0971-6580.128811

18. Ak AT, Alpoz AR, Bayraktar O, Ertugrul F. Monomer release from resin based dental materials cured with LED and halogen lights. Eur J Dent. 2010 Jan;4(1):34-40.

19. Alanko K, Susitaival P, Jolanki R, Kanerva L. Occupational skin diseases among dental nurses. Contact Dermat. 2004 Feb;50(2):77-82. https://doi.org/10.1111/i.0105-1873.2004.00304.x

20. Brackett MG, Bouillaguet S, Lockwood PE, Rotenberg S, Lewis $\mathrm{JB}$, Messer RL et al. In vitro cytotoxicity of dental composites based on new and traditional polymerization chemistries. J Biomed Mater Res B Appl Biomater. 2007 May;81 (2):397402. https://doi.org/10.1002/jbm.b.30676
21. Darmani H, Al-Hiyasat AS. The effects of BIS-GMA and TEG-DMA on female mouse fertility. Dent Mater. 2006 Apr;22(4):353-8. https://doi.org/10.1016/i.dental.2005.04.029

22. Engelmann J, Leyhausen G, Leibfritz D, Geurtsen W. Effect of TEGDMA on the intracellular glutathione concentration of human gingival fibroblasts. J Biomed Mater Res. 2002;63(6):746-51. https://doi.org/10.1002/jbm.10465

23. Samuelsen JT, Dahl JE, Karlsson S, Morisbak E, Becher R. Apoptosis induced by the monomers HEMA and TEGDMA involves formation of ROS and differential activation of the MAP-kinases p38, JNK and ERK. Dent Mater. 2007 Jan;23(1):34-9. https://doi.org/10.1016/i.dental.2005.11.037

24. Schweikl H, Spagnuolo G, Schmalz G.

Genetic and cellular toxicology of dental resin monomers. J Dent Res. 2006 Oct;85(10):870-7. https://doi.org/10.1177/154405910608501001

25. Repetto G, Peso A, Zurita JL. Neutral red uptake assay for the estimation of cell viability/cytotoxicity. Nat Protoc. 2008;3(7):1125-31. https://doi.org/10.1038/nprot.2008.75

26. Geran RI, Greenberg NH, MacDonald MM. Protocols for screening chemical agents and natural products against animal and other biological systems. Cancer Chemother Rep. 1972;3:208-9.

27. Mosmann T. Rapid colorimetric assay for cellular growth and survival: application to proliferation and cytotoxicity assays. J Immunol Methods. $1983 \mathrm{Dec}$;65(1-2):55-63. https://doi.org/10.1016/0022-1759(83)90303-4

28. Zhao M, Antunes F, Eaton JW, Brunk UT. Lysosomal enzymes promote mitochondrial oxidant production, cytochrome $\mathrm{c}$ release and apoptosis. Eur J Bioch sept 2003 Sep; 270(18): 3778-3786. https://doi.org/10.1046/i.1432-1033.2003.03765.x

29. Fotakis $G$, Timbrell JA. In vitro cytotoxicity assays: comparison of LDH, neutral red, MTT and protein assay in hepatoma cell lines following exposure to cadmium chloride. Toxicol Lett. 2006 Jan;160(2):171-7. https://doi.org/10.1016/j.toxlet.2005.07.001

30. Flury S, Peutzfeldt A, Lussi A. Influence of increment thickness on microhardness and dentin bond strength of bulk fill resin composites. Dent Mater. 2014 https://doi.org/10.1016/i.dental.2014.07.001

31. Garoushi S, Vallittu P, Shinya A, Lassila L. Influence of increment thickness on light transmission, degree of conversion and micro hardness of bulk fill composites. Odontology. 2016 Sep;104(3):291-7. https://doi.org/10.1007/s10266-015-0227-0

32. Zorzin J, Maier E, Harre S, Fey T, Belli R, Lohbaver U et al. Bulk-fill resin composites: polymerization properties and extended light curing. Dent Mater. 2015 Mar;31(3):293-301. https://doi.org/10.1016/i.dental.2014.12.010

33. ALShaafi MM, Haenel T, Sullivan B, Labrie D, Alqahtani $M Q$, Price RB. Effect of a broad-spectrum LED curing light on the Knoop microhardness of four posterior resin based composites at 2, 4 and 6-mm depths. J Dent. 2016 Feb;45:14-8. https://doi.org/10.1016/i.jdent.2015.11.004 
- Physicomechanical characterization and biological evaluation of bulk-fill composite resin

34. Alshali RZ, Silikas N, Satterthwaite JD. Degree of conversion of bulk-fill compared to conventional resin-composites at two time intervals. Dent Mater. 2013 Sep;29(9):e213-7. https://doi.org/10.1016/i.dental.2013.05.011

35. Alrahlah A, Silikas N, Watts DC. Post-cure depth of cure of bulk fill dental resin-composites. Dent Mater. 2014 Feb;30(2):149-54. https://doi.org/10.1016/i.dental.2013.10.011

36. Conditt M, Leinfelder K. Improving the polymerization of composite resins. Pract Proced Aesthet Dent. 2006 Apr;18(3):169-71.

37. Sahbaz C, Bahsi E, Ince B, Bakir EP, Cellik O. Effect of the different finishing and polishing procedures on the surface roughness of three different posterior composite resins. Scanning. 2016 Sep;38(5):448-54. https://doi.org/10.1002/sca.21295

38. Checketts MR, Turkyilmaz I, Asar NV. An investigation of the effect of scaling-induced surface roughness on bacterial adhesion in common fixed dental restorative materials. J Prosthet Dent. 2014 Nov; 112(5):1265-70. https://doi.org/10.1016/i.prosdent.2014.04.005

39. Berger SB, Palialol AR, Cavalli V, Giannini M. Surface roughness and staining susceptibility of composite resins after finishing and polishing. J Esthet Restor Dent. 2011 Feb;23(1):34-43. https://doi.org/10.1111/j.1708-8240.2010.00376.x 